\title{
Regulation of the Conversion of Thyroxine to Triiodothyronine in the Perfused Rat Liver
}

\author{
Anthony S. Jennings, Duncan C. Ferguson, and Robert D. Utiger, \\ Endocrine Section, Department of Medicine, University of \\ Pennsylvania School of Medicine, Philadelphia, Pennsylvania 19104
}

A B S T RACT This study was undertaken to determine what factors control the conversion of thyroxine $\left(\mathrm{T}_{4}\right)$ to triiodothyronine $\left(\mathrm{T}_{3}\right)$ in rat liver under conditions approximating those found in vivo. Conversion of $T_{4}$ to $T_{3}$ was studied in the isolated perfused rat liver, a preparation in which the cellular and structural integrity is maintained and that can perform most of the physiologic functions of the liver. The perfused liver readily extracted $\mathrm{T}_{4}$ from perfusion medium and converted it to $T_{3}$. Production of $T_{3}$ by the perfused liver was a function of the size of the liver, the uptake of $\mathrm{T}_{4}$ by the liver, and the presence of $T_{4}-5^{\prime}$-deiodinase activity. Production of $T_{3}$ was increased by increasing the uptake of $\mathrm{T}_{4}$ by liver, which could be accomplished by increasing the liver size, by increasing the perfusate $T_{4}$ concentration, or by decreasing the perfusate albumin concentration. These changes occurred without altering the conversion of $T_{4}$ to $T_{3}$. The liver had a large capacity for extracting $T_{4}$ and for $T_{4}-5$-deiodination to $T_{3}$, which was not saturated at a $\mathrm{T}_{4}$ concentration of $60 \mu \mathrm{g} / \mathrm{dl}$. Production of $T_{3}$ was decreased by inhibiting hepatic $T_{4}-5^{\prime}$ deiodinase with propylthiouracil, which decreased $T_{3}$ production by decreasing the conversion of $T_{4}$ to $T_{3}$. Propylthiouracil did not alter hepatic $\mathrm{T}_{4}$ uptake.

Fasting resulted in a progressive decrease in hepatic $\mathrm{T}_{4}$ uptake to $42 \%$ of control levels by the $3 \mathrm{rd} \mathrm{d}$ of fasting; this was accompanied by a proportionate decrease in $T_{3}$ production. The rate of conversion of $T_{4}$ to $T_{3}$ did not change during fasting. When $T_{4}$ uptake in 2-d-fasted rat livers was raised to levels found in fed rats by increasing the perfusate $T_{4}$ concentration from 10 to $30 \mu \mathrm{g} / \mathrm{dl}, \mathrm{T}_{3}$ production returned to normal. Again, no change in the rate of conversion of $T_{4}$ to $T_{3}$ was observed.

Presented in part at the Annual Meeting of The American Society for Clinical Investigation, Washington, D. C., 6 May 1979 (1979. Clin. Res. 27: 449A.).

Dr. Utiger's present address is the Department of Medicine, University of North Carolina, Chapel Hill, N. C. 27514.

Received for publication 28 December 1978 and in revised form 23 August 1979.
These results indicate that the decreased hepatic $\mathrm{T}_{3}$ production during fasting primarily results from decreased hepatic uptake of $T_{4}$, rather than from changes in $\mathrm{T}_{4}-5^{\prime}$-deiodinase activity. Thus, these studies have delineated a new mechanism that functions independently of enzyme quantity or activity whereby production of $T_{3}$ from $T_{4}$ is regulated.

\section{INTRODUCTION}

Many tissues are known to deiodinate thyroxine $\left(T_{4}\right)^{1}$ with the resultant production of $3,5,3^{\prime}$-triiodothyroxine $\left(T_{3}\right)(1-9)$, but only recently has it been appreciated that most of the circulating $\mathrm{T}_{3}$ is derived from extrathyroidal 5 '-monodeiodination of $\mathrm{T}_{4}$ rather than from thyroidal secretion (10-13). This deiodination increases the metabolic effect of $T_{4}$ because $T_{3}$ is more potent than $T_{4}$. Additional studies have shown that $\mathrm{T}_{4}$ can also undergo 5-monodeiodination in extrathyroidal tissues with the formation of $3,3^{\prime}, 5^{\prime}$ triiodothyronine $\left(\mathrm{rT}_{3}\right)(14,15)$; this mechanism accounts for nearly all of the daily $\mathrm{rT}_{3}$ production. Unlike $\mathrm{T}_{3}, \mathrm{rT}_{3}$ has little intrinsic metabolic activity, though it inhibits the conversion of $T_{4}$ to $T_{3}$ in vitro $(16,17)$. These alternate pathways of $T_{4}$ metabolism provide a mechanism whereby the metabolic effects of $T_{4}$ can be regulated by decreasing the availability of $T_{3}$ to tissues. That such regulation occurs is suggested by the findings of decreased serum $\mathrm{T}_{3}$ concentrations in humans during starvation, acute and chronic illness, in the fetus, and in response to several pharmacologic agents $(18,19)$. Kinetic studies in fasted or cirrhotic patients directly demonstrated decreased peripheral conversion of $T_{4}$ to $T_{3}(15,20)$. However, the elevated serum $\mathrm{rT}_{3}$ concentrations were found to result primarily from decreased $\mathrm{rT}_{3}$ degradation rather than from increased $\mathrm{rT}_{3}$ production. In vitro studies using rat liver homogenates and slices have shown that fasting is asso-

${ }^{1}$ Abbreviations used in this paper: BSA, bovine serum albumin; KHBB, Krebs-Henseleit bicarbonate buffer; MMI, methimazole; PTU, propylthiouracil; $\mathrm{rT}_{3}, 3,3^{\prime}, 5^{\prime}$-triiodothyronine; $T_{4}$, thyroxine; $T_{3}, 3,5,3^{\prime}$-triiodothyronine. 
ciated with decreased generation of $T_{3}$ from $T_{4}(17$, 21,22 ) and decreased $\mathrm{rT}_{3}$ degradation (17) and have suggested that decreased $\mathrm{T}_{4^{-}}-5^{\prime}$-deiodinase activity was responsible for these changes. Although it is clear that hepatic $\mathrm{T}_{4}-5^{\prime}$-deiodinase activity is decreased in fasted rats, it is not clear whether the liver produces less $T_{3}$ from $\mathrm{T}_{4}$ during fasting or, if it does, that decreased deiodinase activity is responsible for decreased $T_{3}$ production under physiologic conditions in vivo. This study was undertaken to determine what factors control the production of $T_{3}$ from $T_{4}$ using the isolated perfused liver, a preparation in which cellular and structural integrity are preserved, and that is capable of performing most of the physiologic functions of the liver.

\section{METHODS}

Materials. $\mathrm{T}_{3}, \mathrm{~T}_{4}$, bovine serum albumin (BSA), propylthiouracil (PTU), and methimazole (MMI) were purchased from Sigma Chemical Co., St. Louis, Mo. The $\mathrm{T}_{3}$ and $\mathrm{T}_{4}$ used in perfusions were dissolved in $0.01 \mathrm{~N} \mathrm{NaOH}(100 \mu \mathrm{g} / \mathrm{ml})$ and stored at $-20^{\circ} \mathrm{C}$. $\left[{ }^{125} \mathrm{I}\right] \mathrm{T}_{3}$ and $\left[{ }^{125} \mathrm{I}\right] \mathrm{T}_{4}$ were prepared by iodination of $3,5-T_{2}$ and $T_{3}$, respectively, using previously described techniques (23). Iobead resin was purchased from Technicon Instruments Corp., Tarrytown, N. Y.

Animals. Male Sprague-Dawley rats weighing 250-300 g were used in all experiments. The animals were fed Wayne Lab-Blox rat feed (Allied Mills, Inc., Chicago, Ill.) and had free access to tap water. In each study, rats from one shipment were used and the mean animal weight for each group was comparable. In the fasting studies, each group of rats was matched for weight before the initiation of fasting. Fasting was begun at 9 a.m. and the perfusions performed between 9 a.m. and 1 p.m. To study the effect of PTU in vivo, rats were given PTU as a $0.05 \%$-solution in $25 \%$ glucose (to enhance its palatability) for $3 \mathrm{~d}$ in place of drinking water. As a control, another group of rats was given $25 \%$ glucose for $3 \mathrm{~d}$ in place of drinking water.

Technique of rat liver perfusion. A modification of the method of Exton and Park $(24,25)$ was used for isolation and perfusion of the rat liver in situ. After induction of anesthesia with intraperitoneal sodium pentobarbital $(60 \mathrm{mg} / \mathrm{kg}$ ) (Abbott Laboratories, North Chicago, Ill.), the abdomen was opened and ligatures placed around the inferior vena cava above the right renal vein, the superior mesenteric and celiac arteries, and the portal vein. A cannula was rapidly inserted into the portal vein and the perfusion pump started. The vena cava below the right renal vein was then cut, allowing perfusion medium to flow through the liver and escape; the ligatures around the portal vein and the arteries were tied. The thorax was then opened and an outflow cannula inserted through the right atrium into the thoracic vena cava. Finally, the ligature around the abdominal inferior vena cava was tied, thus closing the circuit. The perfusate leaving the liver flowed by gravity to a reservoir $15-20 \mathrm{~cm}$ below the liver and was subsequently recirculated. The livers contained little endogenous blood by the time the circuit was completed because, when perfused with buffer containing no BSA or erythrocytes, the livers lost all color and the perfusate leaving the liver contained few erythrocytes $\left(<5,000 / \mathrm{mm}^{3}\right)$ and little protein $(<0.1 \mathrm{mg} / \mathrm{ml})$. Livers were perfused for $1-2 h$ and in any study the perfusion duration was identical in all animals (see figure legends for exact perfusion times).
The perfusion medium consisted of Krebs-Henseleit bicarbonate buffer (KHBB) containing BSA ( $3 \mathrm{~g} / \mathrm{dl}$ except when otherwise stated) and sufficient outdated human erythrocytes to give a hematocrit of $12-16 \%$. The BSA was initially prepared as a $25 \mathrm{~g} / \mathrm{dl}$ solution in KHBB, which was dialyzed for $48 \mathrm{~h}$ at $4^{\circ} \mathrm{C}$ against three to four changes of KHBB. The erythrocytes were washed twice with $2-3$ vol of both $0.9 \% \mathrm{NaCl}$ and $\mathrm{KHBB}$ before use. Because leukocytes are reported to concentrate amino acids (26) and to convert $\mathrm{T}_{4}$ to $\mathrm{T}_{3}$ and $\mathrm{rT}_{3}(27)$, the leukocyte layer was carefully aspirated with each washing. Unless otherwise stated, the $T_{4}$ and glucose concentrations were $10 \mu \mathrm{g} / \mathrm{dl}$ and $100 \mathrm{mg} / \mathrm{dl}$, respectively. The medium $(95 \mathrm{ml})$ was equilibrated in the apparatus with $95 \% \mathrm{O}_{2}-5 \% \mathrm{CO}_{2}$ before perfusion to achieve a temperature of $37^{\circ} \mathrm{C}$ and a $\mathrm{pH}$ of 7.4. The final volume in the system when the circuit was complete was $56-58 \mathrm{ml}$, and care was taken to keep the final volume as constant as possible from perfusion to perfusion.

Using this technique the preparation was routinely completed within 4-6 min after opening the abdomen, and at no time was the liver unperfused. For the duration of the perfusion, livers from fed rats appeared grossly normal and maintained a normal oxygen consumption and bile production $(2.31 \pm 0.20[\mathrm{SEM}] \mu \mathrm{mol} / \mathrm{min}$ perg liver, $n=8 ; 49.3 \pm 1.1$ $\mu \mathrm{l} / \mathrm{h}$ per $\mathrm{g}$ liver, $n=8)$. No liver swelling occurred during the perfusion as evidenced by an unchanged wet to dry weight ratio (perfused, $2.25 \pm 0.05, n=9$; unperfused, $2.23 \pm 0.04$, $n=8)$ and liver weight to body weight ratio (perfused, $3.92 \pm 0.09 \mathrm{~g} / 100 \mathrm{~g}, n=8$; unperfused, $3.98 \pm 0.06 \mathrm{~g} / 100 \mathrm{~g}$, $n=8$ ). The metabolic normalcy of the preparation was evidenced by attainment of maximal rates of gluconeogenesis from lactate $(20 \mathrm{mM}), 96 \pm 5 \mu \mathrm{mol} / \mathrm{g}$ per $\mathrm{h}, n=7$, during the first $15 \mathrm{~min}$ of perfusion in 48-h-fasted rats (24).

Samples $(1 \mathrm{ml})$ were taken from the reservoir every 30 min and kept on ice until separation of the erythrocytes. The medium was stored at $-20^{\circ} \mathrm{C}$ until assayed. At the end of the perfusion, the pump was stopped, and a $0.6-0.9-\mathrm{g}$ portion of liver was rapidly placed in a preweighted grinding vessel containing $1 \mathrm{ml} 0.01 \mathrm{M} \mathrm{PO}_{4}, 0.15 \mathrm{M} \mathrm{NaCl}, \mathrm{pH} 7.4$, at $4^{\circ} \mathrm{C}$. The grinding vessel was quickly reweighed and then stored at $-70^{\circ} \mathrm{C}$ until further processing. The perfusion medium was then pumped out of the apparatus and its volume determined. The sum of this volume, the volume of the samples removed during the perfusion, and the residual volume, i.e., the volume remaining in the apparatus after evacuation, $\sim 0.5 \mathrm{ml}$, was taken as the initial volume in the recirculating system. The remaining liver was removed and weighed, thus allowing calculation of the total liver weight.

Processing of liver samples. The liver samples were thawed to $4^{\circ} \mathrm{C}$ and then homogenized with a motor driven Teflon (Dupont Instrument Corp., Wilmington, Del.) pestle. The homogenate was twice extracted with $4 \mathrm{ml} 100 \%$ ethanol and the extracts pooled. The pooled extract was stored at $-20^{\circ} \mathrm{C}$ for $24-36 \mathrm{~h}$ to allow further precipitation of liver tissue, recentrifuged, the final volume recorded, and an aliquot stored at $-20^{\circ} \mathrm{C}$ for assay. Using this method, $\left[{ }^{125} \mathrm{I}\right] \mathrm{T}_{3}$ was extracted with an efficiency that was inversely proportional to the liver weight according to the following equation: extraction efficiency $(\%)=-21.6 \times$ liver weight $(\mathrm{g})+91.9$ $(r=0.96, P<0.001)$.

The final $T_{3}$ concentration in the liver extracts was corrected for the extraction efficiency obtained using this formula. The extraction efficiency of $T_{4}$ was not influenced by the weight of the liver sample and averaged $58.93 \pm 0.53 \%$. The efficiency of extraction of $T_{3}$ and $T_{4}$ was unaffected by fasting.

$T_{3}$ and $T_{4}$ determinations in perfusion media. Samples were assayed in quadruplicate using double antibody radio- 
immunoassay methods previously described for serum (28, 29). The $T_{3}$ assay conditions were identical to the serum assay with the following exceptions: $(a)$ use of $\left[{ }^{125} \mathrm{I}\right] \mathrm{T}_{3}$ of a high specific activity (23); (b) dilution of anti- $\mathrm{T}_{3}$ antibody to a final dilution of $1: 15,000$; and $(c)$ preparation of the standard curve with KHBB and the appropriate concentration of BSA. The sensitivity of this assay was 4-8 pg $T_{3} /$ tube. The perfusate $T_{4}$ assay was identical to the serum assay except the standards were prepared with KHBB and BSA. Assay sensitivity was $20 \mathrm{pg} /$ tube. Deiodination of $\left.{ }^{125} \mathrm{I}\right] \mathrm{T}_{3}$ was determined using Iobeads, an ion exchange resin that removes inorganic iodide from aqueous solutions.

$T_{3}$ and $T_{4}$ determinations in liver extracts. These determinations were carried out in quadruplicate using double antibody radioimmunoassay techniques as previously described (17). The sensitivity of the assays was 4-8 pg/tube for $T_{3}$ and 20-40 pg/tube for $T_{4}$. Varying the volume of liver extract from 10 to $100 \mu \mathrm{l}$ resulted in linear dose-response curves.

Calculations. The uptake of $\mathrm{T}_{4}$ by the liver was calculated by the following formulas: $(a) \mathrm{T}_{4}$ uptake $=$ (initial $\mathrm{T}_{4}$ concentration - final concentration) $\times$ mean corrected perfusion volume; $(b)$ mean corrected perfusion volume $=$ final volume - [erythrocyte volume $+\mathbf{0 . 5}$ (sample volume removed during perfusion)].

The appearance of $T_{3}$ in the perfusion medium was calculated as follows: $(c) \mathrm{T}_{3}$ appearance (perfusate) $=($ final $T_{3}$ concentration - initial $T_{3}$ concentration $) \times$ mean corrected perfusion volume.

The appearance of $T_{3}$ in the liver was calculated by subtracting, from the observed liver $\mathrm{T}_{3}$ concentration, the mean liver $T_{3}$ concentration in a comparable group of rats following perfusion with medium containing no $\mathrm{T}_{4}$ and multiplying this difference by the total liver weight. Perfusion with medium containing no $\mathrm{T}_{4}$ did not alter the endogenous liver $T_{3}$ concentration in either fed or fasted rats. Thus, $T_{3}$ production was calculated as the sum of the perfusate and liver productions. This does not take into account any biliary secretion of $T_{3}$ and its conjugates or deiodination of $T_{3}$ by liver (see Results). The conversion of $\mathrm{T}_{4}$ to $\mathrm{T}_{3}$ was calculated by dividing the $T_{3}$ production by the $T_{4}$ taken up by the liver.

Expression of results. The uptake of $\mathrm{T}_{4}$ and the production of $\mathrm{T}_{3}$ are expressed relative to the wet weight of the liver in grams except when an experimental manipulation resulted in a change in liver size between groups, i.e., fed vs. fasted animals (see Results, Fig. 6). When such comparisons were made, $T_{4}$ uptake and $T_{3}$ production were then expressed as the absolute quantity in micrograms or nanograms, respectively.

Statistical evaluation of data. In experiments with two groups of animals, statistical analysis was performed using Student's $t$ test. When three or more treatment groups were studied, a one-way analysis of variance was performed and Duncan's multiple range test was then applied to identify significant differences among specific groups (30). Data are presented as the mean \pm SEM.

\section{RESULTS}

General characteristics of the perfusion system (Fig. 1). When perfused at a $\mathrm{T}_{4}$ concentration of 10 $\mu \mathrm{g} / \mathrm{dl}$, a BSA concentration of $4 \%$, and a flow rate of 1.5 $\mathrm{ml} / \mathrm{g}$ liver per min, the rat liver readily extracted $\mathrm{T}_{4}$ from the media as evidenced by a significant decline in the perfusion medium $\mathrm{T}_{4}$ concentration by $30 \mathrm{~min}$ $(P<0.001)$. Though the $\mathrm{T}_{4}$ concentration continued to
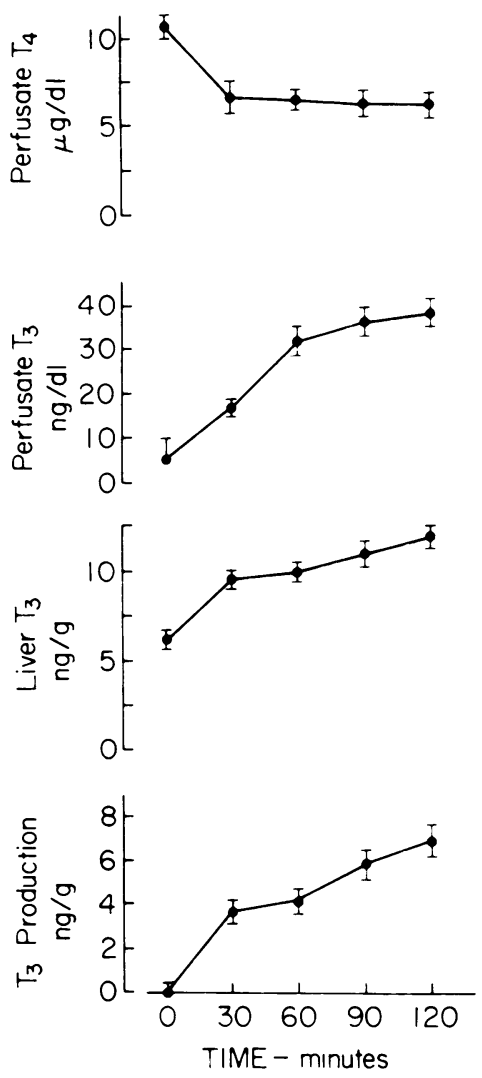

FIGURE 1 Changes in perfusate $T_{4}$ and $T_{3}$ concentration, liver $T_{3}$ concentration, and $T_{3}$ production during perfusion. The perfusion medium contained $4 \mathrm{~g} / \mathrm{dl} \mathrm{BSA}$ and $10 \mu \mathrm{g} / \mathrm{dl}$ $T_{4}$. The perfusate data in the upper two panels represent points (mean $\pm S E M$ ) obtained from eight 2 -h perfusions. Corresponding points in the lower two panels represent the mean \pm SEM of eight perfusions of the indicated duration.

fall during the course of the perfusion, this decline was minimal and subsequent $T_{4}$ concentrations were not significantly lower than the 30 -min value. The extraction of $\mathrm{T}_{4}$ by the liver was associated with a prompt, significant increase in both the perfusate $\mathrm{T}_{3}$ concentration $(P<0.001)$ and the liver $\mathrm{T}_{3}$ concentration $(P<0.001)$ by $30 \mathrm{~min}$. The perfusate $\mathrm{T}_{3}$ concentration increased in a linear fashion for $60-90 \mathrm{~min}$ before reaching a plateau, whereas the liver $\mathrm{T}_{3}$ concentration increased most dramatically in the first $30 \mathrm{~min}$ of perfusion, followed by a more gradual but linear increase thereafter. Total $T_{3}$ production (perfusate + liver) increased the most in the first $30 \mathrm{~min}$ of perfusion, coincident with the period of rapid $\mathrm{T}_{4}$ uptake by the liver. $T_{3}$ production proceeded in a linear fashion thereafter, though at a slower rate. The $\mathrm{T}_{3}$ in the perfusate generally accounted for $20-30 \%$ of the total $\mathrm{T}_{3}$ production. Approximately $2-4 \%$ of the $\mathrm{T}_{4}$ extracted by the liver was converted to $\mathrm{T}_{3}$ in 1-2 $\mathrm{h}$ of perfusion. When livers were perfused with media containing no 
$T_{4}$, neither $T_{3}$ nor $T_{4}$ could be detected in the perfusion media. Likewise, when media containing $T_{4}$ was circulated in the system without a liver, no $\mathrm{T}_{3}$ production was demonstrable.

Effect of perfusion flow rate (Table I). When livers were perfused at different flow rates based on the average liver wt/100 $\mathrm{g}$ body wt, $\mathrm{T}_{3}$ production was maximal at flow rates of $1.0-1.5 \mathrm{ml} / \mathrm{g}$ liver per $\mathrm{min}$. When perfused at $3 \mathrm{ml} / \mathrm{g}$ liver per minute, $\mathrm{T}_{3}$ production was significantly lower $(P<0.05)$. The hepatic extraction of $\mathrm{T}_{4}$ was unaffected by these variations in flow rate. All subsequent studies were performed using a flow rate of $1.5 \mathrm{ml} / \mathrm{g}$ liver per min.

Effect of perfusate glucose concentration (Table II). Varying the glucose concentration from 0 to $300 \mathrm{mg} / \mathrm{dl}$ had no effect on $T_{3}$ production at an initial perfusate $T_{4}$ concentration of either 10 or $30 \mu \mathrm{g} / \mathrm{dl}$. Similarly, $\mathrm{T}_{3}$ production by livers from fasted rats was the same at medium glucose concentrations of 40,100 , and 300 $\mathrm{mg} / \mathrm{dl}$. The addition of insulin to perfusion medium containing 100 or $300 \mathrm{mg} / \mathrm{dl}$ glucose had no effect on $\mathrm{T}_{3}$ production by livers from either fed or fasted rats.

Effect of perfusion with $T_{3}$. When perfused for $1 \mathrm{~h}$ with $\mathrm{T}_{3}, 60 \mathrm{ng} / \mathrm{dl}$, and tracer amounts of $\left[{ }^{125} \mathrm{I}\right] \mathrm{T}_{3}$, $68.5 \pm 1.0 \%(n=4)$ of the ${ }^{[125} \mathrm{I}^{1} \mathrm{~T}_{3}$ was taken up by the liver in fed rats, and $54.6 \pm 2.1 \%(n=4)$ in fasted rats. Biliary excretion of ${ }^{125} \mathrm{I}^{1} \mathrm{~T}_{3}$ represented $12.4 \pm 2.4 \%$ $(n=4)$ of the total $\left.{ }^{125} \mathrm{I}\right] \mathrm{T}_{3}$ in the system in fed rats and $14.7 \pm 0.6 \%$ in fasted animals. Deiodination of $\left.{ }^{125} \mathrm{I}\right] \mathrm{T}_{3}$ was $12.0 \pm 1.3 \%(n=4)$ in fed rats and 11.7 $\pm 0.8 \%(n=4)$ in fasted rats. Neither the biliary excretion nor the deiodination of $\mathrm{T}_{3}$ were used in calculating $\mathrm{T}_{3}$ production in the system and therefore the reported values underestimate the true production. However, it is clear that differences in biliary excretion or deiodination cannot explain any difference between fed and fasted rats.

Effect of liver weight (Fig. 2). When livers of fed rats were perfused at a $T_{4}$ concentration of $10 \mu \mathrm{g} / \mathrm{dl}$ and a BSA concentration of $3 \mathrm{~g} / \mathrm{dl}$, large rat livers $(12.65 \pm 0.75 \mathrm{~g})$ took up more $\mathrm{T}_{4}(P<0.02)$ and produced more $\mathrm{T}_{3}(P<0.05)$ than did small rat livers $(7.65 \pm 0.52 \mathrm{~g})$. Both $\mathrm{T}_{4}$ uptake and $\mathrm{T}_{3}$ production were

TABLE I

Effect of Perfusion Flow Rate on $T_{3}$ Production and $T_{4}$ Uptake

\begin{tabular}{ccc}
\hline Flow rate & $\mathrm{T}_{3}$ production & $\mathrm{T}_{\text {4 uptake }}$ \\
\hline ml/g/min & $n g / g / 2 h$ & $\mu \mathrm{g} / \mathrm{g} / 2 \mathrm{~h}$ \\
1.0 & $5.99 \pm 0.87$ & $0.18 \pm 0.02$ \\
1.5 & $6.87 \pm 0.82$ & $0.15 \pm 0.02$ \\
3.0 & $2.76 \pm 0.64$ & $0.16 \pm 0.01$
\end{tabular}

Perfusion medium contained $4 \mathrm{~g} / \mathrm{dl} \mathrm{BSA}$ and $10 \mu \mathrm{g} / \mathrm{dl} \mathrm{T}_{4}$. Perfusions were of $2 \mathrm{~h}$ duration.
TABLE II

$T_{3}$ Production (ng/g/90 min) with Varying Concentrations of Glucose

\begin{tabular}{lccr}
\hline & \multicolumn{3}{c}{ Glucose concentration } \\
\cline { 2 - 4 } & \multicolumn{1}{c}{100} & \multicolumn{1}{c}{300} \\
\hline & & $m g / d l$ \\
$\mathrm{~T}_{4}-30 \mu \mathrm{g} / \mathrm{dl}$ & $16.25 \pm 2.21$ & $14.04 \pm 1.82$ & $14.96 \pm 0.80$ \\
$\mathrm{~T}_{4}-10 \mu \mathrm{g} / \mathrm{dl}$ & & $3.66 \pm 0.25$ & $4.44 \pm 0.82$
\end{tabular}

Perfusion medium contained $4.0 \mathrm{~g} / \mathrm{dl}$ BSA. Perfusions were of $1.5 \mathrm{~h}$ duration.

increased in proportion to the increased liver weight for the reason that values were not different when expressed on a per gram basis. There was no difference in the conversion of $T_{4}$ to $T_{3}$.

Effects of the perfusate $T_{4}$ concentration(Fig. 3). Increasing the perfusate $T_{4}$ concentration from 3 to 60 $\mu \mathrm{g} / \mathrm{dl}$, at a BSA concentration of $4 \mathrm{~g} / \mathrm{dl}$, resulted in a progressive increase in $T_{4}$ uptake by the liver ( $P$ $<0.001$ for 30 and $60 \mu \mathrm{g} / \mathrm{dl}$ vs. 3 and $10 \mu \mathrm{g} / \mathrm{dl}$ ). This increase in $\mathrm{T}_{4}$ uptake was associated with an increased $\mathrm{T}_{3}$ production $(P<0.005$ and $<0.001$ for 30 and 60 $\mu \mathrm{g} / \mathrm{dl}$ vs. 3 and $10 \mu \mathrm{g} / \mathrm{dl})$. No differences in the percent conversion of $T_{4}$ to $T_{3}$ were found as the $T_{4}$ concentration was increased, again indicating that a relatively constant fraction of the extracted $T_{4}$ was converted to $T_{3}$. Even with a perfusate $T_{4}$ concentration of 60 $\mu \mathrm{g} / \mathrm{dl}$, the maximal response may not have been obtained. It is important to note that at $\mathrm{T}_{4}$ concentrations
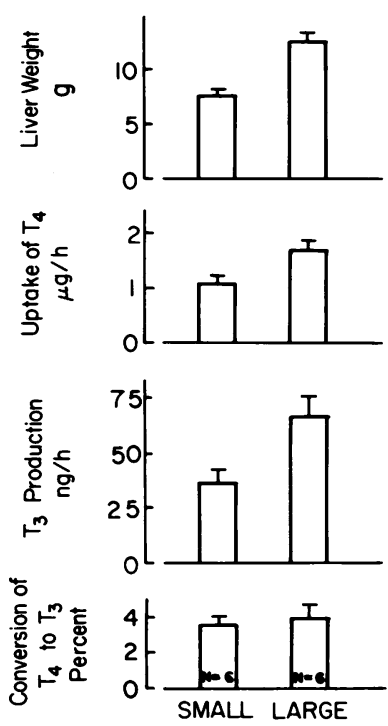

FIGURE 2 Effect of liver weight on the uptake of $T_{4}, T_{3}$ production, and conversion of $T_{4}$ to $T_{3}$ in fed rats. Perfusion medium contained $3 \mathrm{~g} / \mathrm{dl}$ BSA and $10 \mu \mathrm{g} / \mathrm{dl} \mathrm{T}_{4}$. Perfusions were $1 \mathrm{~h}$ in duration. Values shown are mean \pm SEM. 


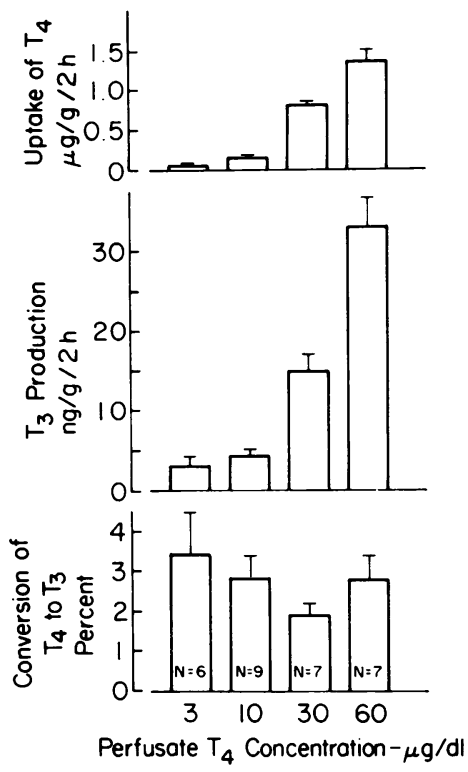

Figure 3 Effect of perfusate $T_{4}$ concentration on the uptake of $T_{4}, T_{3}$ production, and conversion of $T_{4}$ to $T_{3}$. The perfusate BSA concentration was $4 \mathrm{~g} / \mathrm{dl}$. Perfusions were $2 \mathrm{~h}$ in duration. Values shown are mean $\pm S E M$.

similar to those found in the rat, i.e., 3-10 $\mu \mathrm{g} / \mathrm{dl}$, the slope of the dose response was shallow and an increase in the perfusate $T_{4}$ concentration was not associated by a proportionate increase in either $T_{4}$ uptake or $\mathrm{T}_{3}$ production.
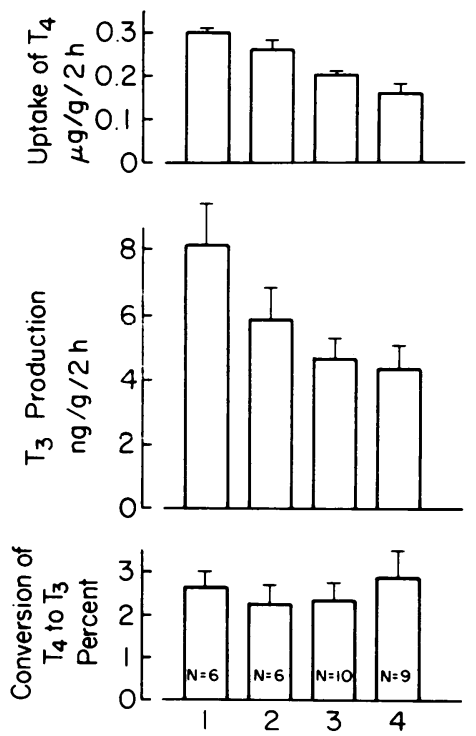

Albumin Concentration $-g / d l$

Figure 4 Effect of perfusate albumin concentration on the uptake of $T_{4}, T_{3}$ production, and conversion of $T_{4}$ to $T_{3}$. The perfusate $T_{4}$ concentration was $10 \mu \mathrm{g} / \mathrm{dl}$. Perfusions were $2 \mathrm{~h}$ in duration. Values shown are mean \pm SEM.
Effects of the perfusate BSA concentration (Fig. 4). Increasing the perfusate BSA concentration from 1 to $4 \mathrm{~g} / \mathrm{dl}$, at a $\mathrm{T}_{4}$ concentration of $10 \mu \mathrm{g} / \mathrm{dl}$, resulted in a progressive stepwise reduction in the uptake of $\mathrm{T}_{4}$ by the liver $(P<0.001$ for 3 and $4 \mathrm{~g} / \mathrm{dl}$ vs. $1 \mathrm{~g} / \mathrm{dl})$. This reduction in $T_{4}$ uptake was associated with a concomitant reduction in $\mathrm{T}_{3}$ production $(P<0.05$ for 3 and $4 \mathrm{~g} / \mathrm{dl}$ vs. $1 \mathrm{~g} / \mathrm{dl}$ ). No difference in the percent conversion of $T_{4}$ to $T_{3}$ was observed as the BSA concentration was increased, indicating that the quantity of $\mathrm{T}_{3}$ produced was directly proportional to the quantity of $\mathrm{T}_{4}$ taken up by the liver.

Effects of PTU and MMI (Fig. 5). Because PTU is an inhibitor of $\mathrm{T}_{4}-5^{\prime}$-deiodinase activity in homogenate systems $(16,17)$, perfusion with PTU should inhibit $\mathrm{T}_{3}$ production by decreasing the percent conversion of $\mathrm{T}_{4}$ to $\mathrm{T}_{3}$. When livers of fed rats were perfused with media containing PTU $(58.7 \mu \mathrm{M})$, a significant reduction in both $\mathrm{T}_{3}$ production $(P<0.001)$ and the percent conversion of $\mathrm{T}_{4}$ to $\mathrm{T}_{3}(P<0.001)$ was found. Likewise, when PTU was given to rats as a $0.05 \%$ solution in $25 \%$ glucose, a significant reduction in both $\mathrm{T}_{3}$ production $(P<0.001)$ and percent conversion of $\mathrm{T}_{4}$ to $\mathrm{T}_{3}(P<0.001)$ was found when compared with rats given only $25 \%$ glucose. Addition of MMI $(87.7$ $\mu \mathrm{M})$ to perfusion media had no effect on $\mathrm{T}_{3}$ production.

Effects of fasting (Fig. 6). Fasting for 1-3 d was
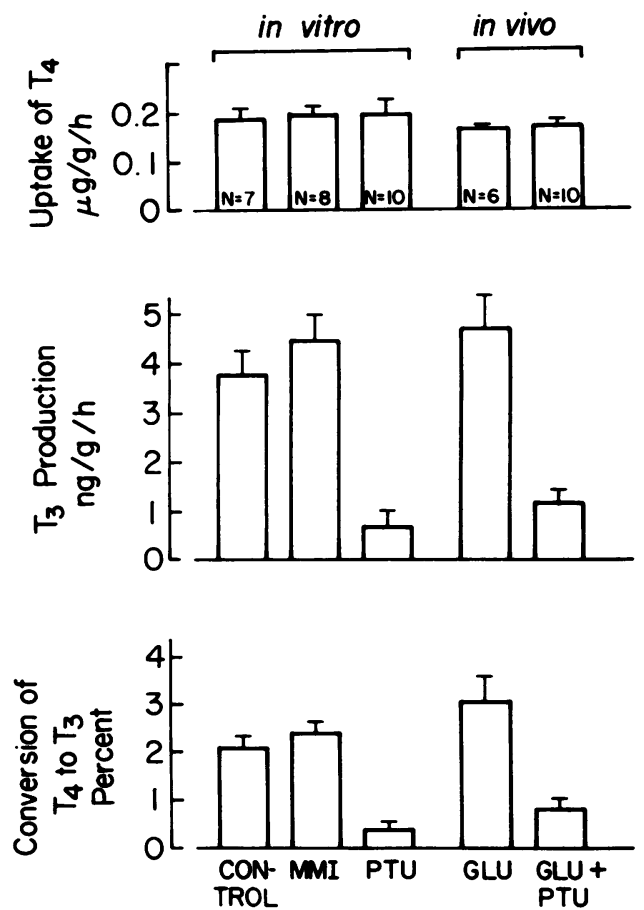

FIgure 5 Effect of MMI and PTU on the uptake of $T_{4}, T_{3}$ production, and $T_{4}$ conversion to $T_{3}$. The perfusion medium contained $3 \mathrm{~g} / \mathrm{dl} \mathrm{BSA}$ and $10 \mu \mathrm{g} / \mathrm{dl} \mathrm{T}_{4}$. Perfusions were $1 \mathrm{~h}$ in duration. Values shown are mean \pm SEM. 
associated with a significant decline in the total liver weight (fed, $11.28 \pm 0.38 \mathrm{~g} ; 1$-d fast, $7.91 \pm 0.29 \mathrm{~g}$ ( $P$ $<0.001)$; 2-d fast, $6.78 \pm 0.23 \mathrm{~g}(P<0.001)$; 3-d fast, $6.08 \pm 0.40 \mathrm{~g}(P<0.001)$. Although the hepatic uptake of $\mathrm{T}_{4}$ on a per gram basis did not change during fasting $(0.17 \pm 0.01 \mu \mathrm{g} / \mathrm{g}$ per $\mathrm{h})$, total uptake of $\mathrm{T}_{4}$ decreased from $1.91 \pm 0.14 \mu \mathrm{g} / \mathrm{h}$ in the fed rat to $1.35 \pm 0.15 \mu \mathrm{g} / \mathrm{h}$ after a 1-d fast $(P<0.01), 1.13 \pm 0.11 \mu \mathrm{g} / \mathrm{h}$ after $2 \mathrm{~d}$ $(P<0.001)$, and $1.11 \pm 0.10 \mu \mathrm{g} / \mathrm{h}$ after $3 \mathrm{~d}(P<0.001)$. This decrease in the uptake of $\mathrm{T}_{4}$ was associated with a concomitant fall in total $T_{3}$ production from $39.7 \pm 7.9$ to $19.7 \pm 2.9 \mathrm{ng} / \mathrm{h}$ by day $2(P<0.005)$ and to $16.8 \pm 1.4$ $\mathrm{ng} / \mathrm{h}(P<0.005)$ on day 3 . This fall in $\mathrm{T}_{3}$ production during fasting was the result of decreased hepatic extraction of $T_{4}$, as there was no significant change in the rate of conversion of $T_{4}$ to $T_{3}$ during fasting. Because the conversion of $T_{4}$ to $T_{3}$ is an index of the deiodinase enzyme activity, these data indicate that the fall in hepatic deiodinase activity reported to occur in fasting did not appreciably contribute to the fall in $T_{3}$ production.

Effect of perfusate $T_{4}$ concentration on $T_{4}$ uptake and $T_{3}$ production in fasting (Fig. 7). If decreased uptake of $T_{4}$ is the primary defect responsible for decreased hepatic $T_{3}$ production in fasting, then in-
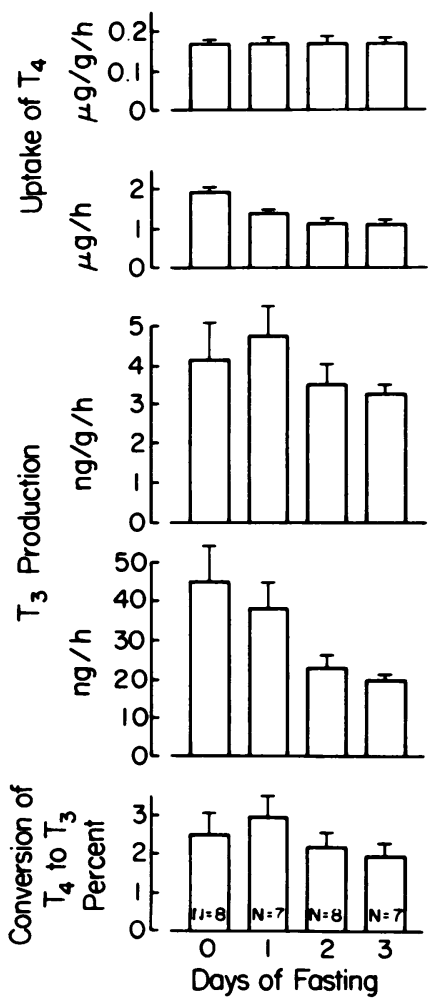

FIGURE 6 Effect of fasting on the uptake of $T_{4}, T_{3}$ production, and conversion of $T_{4}$ to $T_{3}$. The perfusion medium contained $3 \mathrm{~g} / \mathrm{dl} \mathrm{BSA}$ and $10 \mu \mathrm{g} / \mathrm{dl} \mathrm{T}_{4}$. Perfusions were $1 \mathrm{~h}$ in duration. Values shown are mean $\pm \mathrm{SEM}$.
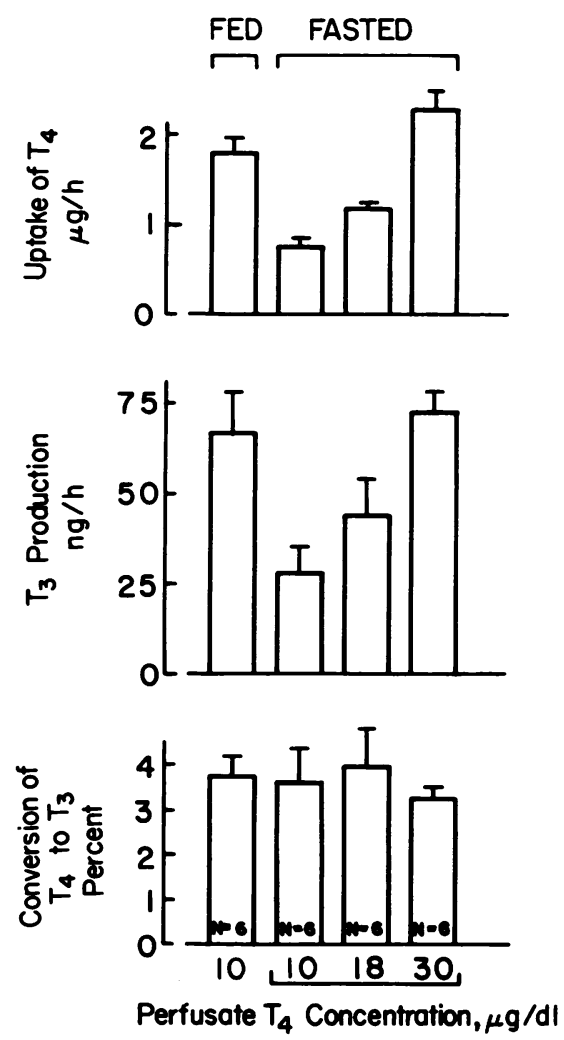

FIGURE 7. Effect of perfusate $T_{4}$ concentration on the uptake of $T_{4}, T_{3}$ production, and conversion of $T_{4}$ to $T_{3}$ in 2-d-fasted rats. The perfusate BSA concentration was $3.0 \mathrm{~g} / \mathrm{dl}$. Perfusions were $1 \mathrm{~h}$ in duration. Values shown are mean $\pm S E M$.

creasing $T_{4}$ uptake to levels found in fed rats should return $T_{3}$ production to normal. When the perfusate $T_{4}$ concentration was increased from 10 to $30 \mu \mathrm{g} / \mathrm{dl}$ in 2-d fasted rats $(3 \mathrm{~g} / \mathrm{dl} \mathrm{BSA}), \mathrm{T}_{4}$ uptake increased progressively to levels found in fed rats. $T_{3}$ production was restored to normal when the perfusate $T_{4}$ concentration was $30 \mu \mathrm{g} / \mathrm{dl}$. The rate of conversion of $T_{4}$ to $T_{3}$ did not change over this range of $T_{4}$ concentrations.

However, when livers of $2-d$ fasted rats were perfused at $100 \mu \mathrm{g} / \mathrm{dl}$, the conversion of $\mathrm{T}_{4}$ to $\mathrm{T}_{3}$ fell from $3.93 \pm 0.66$ to $2.19 \pm 0.25 \%(P<0.05)$. These data indicate that the decline in conversion of $T_{4}$ to $T_{3}$ observed in homogenate preparations in fasted rats can be reproduced in the perfused liver at high, unphysiologic $T_{4}$ concentrations. However, at more physiologic $T_{4}$ concentrations, this phenomenon is not observed.

Effects of fasting on the endogenous liver $T_{3}$ and $T_{4}$ content ( $F$ ig. 8). Fasting was associated with a decrease in the hepatic content of both $T_{3}$ and $T_{4}$ which was statistically significant after $1 \mathrm{~d}$ of fasting $\left(P<0.001\right.$ for both $T_{3}$ and $\left.T_{4}\right)$. The ratio of the content of $T_{3}$ to $T_{4}$ remained relatively constant, between 0.25 to 0.32 , during the course of the fast. This sup- 

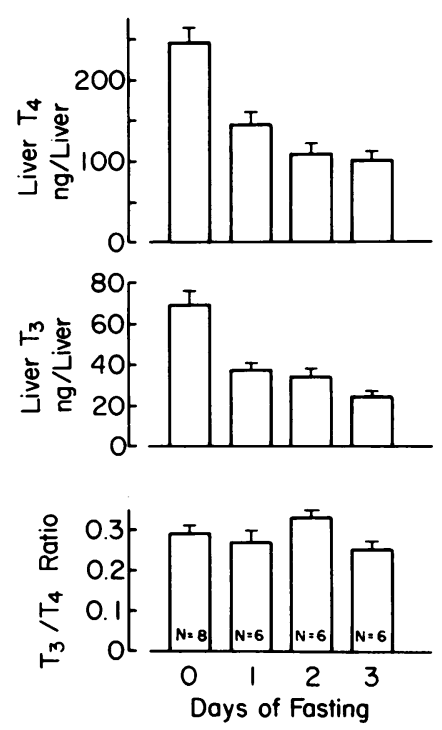

Figure 8 Endogenous liver content of $T_{4}$ and $T_{3}$ and the hepatic $T_{3} / T_{4}$ ratio during fasting. Values shown are mean \pm SEM.

ports the contention that the fall in hepatic deiodinase activity observed during fasting is not the primary regulatory mechanism for decreasing the hepatic production of $T_{3}$ from $T_{4}$ because if it were, a decrease in the hepatic ratio of $T_{3}$ to $T_{4}$ should have been found.

\section{DISCUSSION}

The present studies demonstrate the utility of the perfused rat liver for studying hepatic $T_{3}$ production. The results show that three factors are important in determining hepatic $T_{3}$ production: liver size; $T_{4}$ uptake by the liver; and hepatic $T_{4}-5^{\prime}$-deiodinase activity. The liver was found to have a large capacity for both $\mathrm{T}_{4}$ uptake and $\mathrm{T}_{4}-5^{\prime}$-deiodination, which was not saturated at high, unphysiologic $\mathrm{T}_{4}$ concentrations. Finally, the results show that hepatic production of $T_{3}$ from $T_{4}$ was decreased during fasting and provide evidence that at physiologic concentrations of $T_{4}$, the decline in $T_{3}$ production resulted primarily from decreased hepatic $T_{4}$ uptake rather than from changes in the rate of conversion of $T_{4}$ to $T_{3}$, i.e., in $T_{4}-5^{\prime}$ deiodinase activity.

Previous studies using rat liver homogenates and slices have clearly demonstrated a decrease in $\mathrm{T}_{4^{-}}$ 5 -deiodinase activity during fasting $(17,21,22)$, untreated streptozotocin-induced diabetes (21), hypothyroidism $(22,31-33)$, and in the fetus $(34,35)$. This decrease in $5^{\prime}$-deiodinase activity in fasting has been attributed wholly or in part to deficiency of a cytosol cofactor rather than to a quantitative decrease in the enzyme itself (36-38). Substances that maintain sulfhydryl groups in the reduced state, such as reduced glutathione, NADPH, and dithiothreitol were shown to restore $\mathrm{T}_{\mathbf{4}}-5^{\prime}$-deiodinase activity to normal levels in liver homogenates from fasted rats. In contrast, agents that oxidize sulfhydryl groups, such as diamide, oxidized gluthathione, mercuric chloride, and $\mathrm{N}$ ethylmaleimide, produced a decrease in homogenate deiodinase activity. More recently, PTU, an allosteric inhibitor of deiodinase activity $(16,17)$, was shown to compete with reduced glutathione for a noncatalytic site on the deiodinase enzyme (39). Taken together, these data have suggested that hepatic $5^{\prime}$ deiodinase activity is modulated by altering the availability of reduced sulfhydryl groups, presumably glutathione.

Although these studies have shed considerable light on the biochemistry of $\mathrm{T}_{4}-5^{\prime}$-deiodination, it is not clear whether the decrease in deiodinase activity is the primary regulatory mechanism mediating the decreased conversion of $T_{4}$ to $T_{3}$ under physiologic conditions. The data cited above were obtained primarily from in vitro studies using rat liver homogenates. Such broken cell preparations lack both the control systems associated with intact cellular and organ structure and the ability to respond to metabolic and hormonal perturbations. The incubations were performed in buffer solutions containing little or no binding proteins, with inadequate or absent oxygenation, and using high concentrations of $\mathrm{T}_{4}(50-500$ $\mu \mathrm{g} / \mathrm{dl})$. In such preparations homogenate deiodinase activity had a $K_{\mathrm{m}}$ for $\mathrm{T}_{4}$ of 1.5-7.7 $\mu \mathrm{M}$ (116.5-592.9 $\mu \mathrm{g} / \mathrm{dl})(17,34)$, a priori suggesting lack of a regulatory role because the enzymatic capacity greatly exceeds the quantities of endogenous $\mathrm{T}_{4}$ available for deiodination. Thus, the $50 \%$ reduction in deiodinase activity found in liver homogenates from fasted rats should have little measurable effect on the conversion of $T_{4}$ to $T_{3}$ at physiologic $T_{4}$ concentrations. Finally, homogenate preparations, although allowing study of the enzymatic and biochemical aspects of deiodination, cannot be used to evaluate the possibility that $T_{3}$ neogenesis, like gluconeogenesis, might be regulated by the availability of substrate, i.e., $\mathrm{T}_{4}$, as well as by the prevailing enzyme activity.

Use of the isolated perfused liver obviates some of the above-mentioned problems. The cellular and structural integrity of the liver is maintained in a milieu similar to that of the intact rat. The ability to respond to both substrate and hormonal signals was maintained, and the $T_{4}$ concentration $(10 \mu \mathrm{g} / \mathrm{dl})$ used was close to that found in the normal rat (3-5 $\mu \mathrm{g} / \mathrm{dl}$ ), although the percentage of protein-bound $\mathrm{T}_{4}$ would be lower. The isolated perfused liver readily extracted $\mathrm{T}_{4}$ from the perfusion media and $5^{\prime}$-deiodinated it with the production of $T_{3}$, in accord with previous studies with this preparation (40). The data indicating that $T_{3}$ production at near physiologic con- 
centrations of $T_{4}$ is in some instances regulated by alterations in $T_{4}$ uptake rather than changes in deiodinase activity require elaboration of the distinctions between these processes. Total production of $T_{3}$ is a function of liver size, $T_{4}$ uptake, and $T_{4}-5^{\prime}$ deiodinase activity. In contrast, the percent conversion of $T_{4}$ to $T_{3}$ reflects the fraction of intracellular $T_{4}$ converted to $T_{3}$ and is a function of $T_{4}-5^{\prime}$-deiodinase activity. Only this latter component of $T_{3}$ production can be measured in homogenate systems. In the perfused liver, increasing liver weight resulted in proportionate increases in $T_{4}$ uptake and $T_{3}$ production; the percentage of $T_{4}$ to $T_{3}$ conversion was unchanged. Similarly, $T_{3}$ production increased proportionately when $T_{4}$ uptake was increased by increasing perfusate $\mathrm{T}_{4}$ or decreasing perfusate albumin concentrations. Again, the percentage of $T_{4}$ converted to $T_{3}$ was unchanged, even at a perfusate $T_{4}$ concentration of 60 $\mu \mathrm{g} / \mathrm{dl}$, far exceeding that ever found in vivo. In contrast, PTU decreased $T_{3}$ production by reducing the percent conversion of $T_{4}$ to $T_{3}$, as would be expected of an inhibitor of $\mathrm{T}_{4}-\mathrm{5}^{\prime}$-deiodinase, without altering $\mathrm{T}_{4}$ uptake.

These perfusion results indicate that the primary factor responsible for the decreased hepatic $T_{3}$ production observed during fasting was decreased $T_{4}$ uptake. When rats were fasted for 1-3 d, hepatic $T_{4}$ uptake decreased in proportion to the fall in liver weight. Decreased $\mathrm{T}_{4}$ uptake was accompanied by a proportionate decrease in $T_{3}$ production. There was no change in the conversion of $T_{4}$ to $T_{3}$. Furthermore, when $T_{4}$ uptake by livers from fasted rats was increased to levels found in livers from fed rats, by increasing the perfusate $T_{4}$ concentration from 10 to $30 \mu \mathrm{g} / \mathrm{dl}$, total $\mathrm{T}_{3}$ production was restored to normal. Again, there was no change in the rate of conversion of $T_{4}$ to $T_{3}$. Only at a very high $T_{4}$ concentration $(100 \mu \mathrm{g} / \mathrm{dl})$ was the conversion of $T_{4}$ to $T_{3}$ decreased during fasting. Therefore, at physiologic $\mathrm{T}_{4}$ concentrations, the $50-60 \%$ decrease in $\mathrm{T}_{4}-5^{\prime}$-deiodinase activity in liver homogenates from fasted rats probably does not play a major regulatory role in decreasing hepatic $T_{3}$ production during fasting, consistent with the kinetic measurements in homogenates indicating a high $K_{\mathrm{m}}$ (high capacity) enzyme. The concomitant and proportionate fall in the endogenous liver $T_{4}$ and $T_{3}$ content during fasting further supports the validity of the in vitro findings.

It is important to appreciate that the perfusate-free $\mathrm{T}_{4}$ concentration was higher than that found in normal rat serum because the only $\mathrm{T}_{4}$-binding protein present was albumin, a high capacity, low affinity $\mathrm{T}_{4}$-binding protein $\left(\mathrm{T}_{3}\right.$-resin uptake $35.9 \%$ for rat serum, $47.5 \%$ for $4.0 \% \mathrm{BSA}$ ) and because the $\mathrm{T}_{4}$ concentration (10 $\mu \mathrm{g} / \mathrm{dl}$ ) was two- to three-fold greater than that in normal rat serum $(3-5 \mu \mathrm{g} / \mathrm{dl})$. This was evidenced by the finding that perfusion with a $T_{4}$ concentration of 10 $\mu \mathrm{g} / \mathrm{dl}$ and BSA concentration of $4 \mathrm{~g} / \mathrm{dl}$ increased the liver $\mathrm{T}_{4}$ concentration to $8-10$ times above the endogenous $\mathrm{T}_{4}$ concentration. The perfused liver was therefore driven to produce more $T_{3}$ than usually occurs in vivo because of the increased hepatic uptake of $T_{4}$. In the presence of additional and more potent $T_{4^{-}}$ binding proteins, as are present in serum, $\mathrm{T}_{4}$ uptake by the liver would be less, limiting to a greater extent the $T_{4}$ available for conversion of $T_{3}$. Therefore, under in vivo conditions, the uptake of $\mathrm{T}_{4}$ into the liver would be even more rate limiting for the conversion of $T_{4}$ to $T_{3}$ than was apparent in the perfused liver.

Although these studies underscore the importance of the $T_{4}$ uptake into the liver as a regulatory mechanism for $T_{3}$ production, altered conversion of $T_{4}$ to $T_{3}$ (altered enzyme activity) is also important. This is the mechanism by which PTU inhibits $T_{3}$ production. Preliminary studies in situations of extreme metabolic abnormality, i.e., untreated streptozotocin-induced diabetes, indicate that decreased $T_{3}$ production is a result of both decreased $T_{4}$ uptake and decreased conversion of $T_{4}$ to $T_{3}$ (deiodinase activity). Furthermore, the methods used in the present study may not be sufficiently sensitive to detect small changes in conversion of $T_{4}$ to $T_{3}$.

Decreased hepatic uptake of $T_{4}$ during fasting could result from either decreased activity of a specific transport system for $T_{4}$, decreased quantities of tissue $\mathrm{T}_{4}$-binding proteins, or increased serum concentration of a compound(s) that competed with $\mathrm{T}_{4}$ for either transport sites or $\mathrm{T}_{4}$-binding proteins. Although there is little evidence to support the existence of a specific $\mathrm{T}_{4}$ transport system, there is considerable evidence that hepatic $T_{4}$ uptake is influenced by the quantity and the affinity of $\mathrm{T}_{4}$-binding proteins on each side of the plasma membrane (41-45). The studies reported here demonstrating decreased $\mathrm{T}_{4}$ uptake into the liver with increasing perfusate albumin concentrations provide further validation for this concept. It seems likely that the decreased $\mathrm{T}_{4}$ uptake in fasted rat livers resulted from a decrease in $\mathrm{T}_{4}$-binding proteins in the liver. $\mathrm{A}$ number of cellular proteins have binding sites for $T_{4}$. These proteins are located in a variety of cell fractions including the nucleus $(46,47)$, mitochondria $(48,49)$, microsomes (50), cytosol $(51,52)$, and plasma membranes $(53,54)$. Recent evidence suggests that the binding capacity of both the hepatocyte nucleus (55-57) and cytosol (58) for thyroid hormones is reduced by fasting. Which of the cellular $\mathrm{T}_{4}$-binding proteins is most important in regulating the uptake of $T_{4}$ into the cell and the mechanisms through which these binding sites are regulated remain to be determined.

In summary, the data demonstrate the utility of the isolated perfused liver in the study of $\mathrm{T}_{4}$ metabolism. The results demonstrate the large capacity of the liver for $\mathrm{T}_{4}$ uptake and its 5 '-deiodination to $\mathrm{T}_{3}$. Hepatic 
production of $T_{3}$ from $T_{4}$ was decreased by fasting; this decrease primarily resulted from decreased $T_{4}$ uptake by the liver. The data further suggest, though they do not prove, that the uptake of $\mathrm{T}_{4}$ into the liver is determined by the relative abundance of cellular and extracellular $\mathrm{T}_{4}$ binding sites and that the decreased hepatic uptake of $\mathrm{T}_{4}$ during fasting resulted from loss of cellular $\mathrm{T}_{4}$-binding proteins.

\section{ACKNOWLEDGMENTS}

We thank Mrs. Leona Fields for expert technical assistance and Mrs. Elaine Paolini, Ms. Paula Snyder, and Mrs. Sheila Majors for able secretarial help.

These studies were supported by U. S. Public Health Service grants RO 1 AM 14039, F 32 AM 05851, and GM 02051 (Veterinary Medical Scientist Training Program).

\section{REFERENCES}

1. Albright, E. C., F. C. Larson, and J. R. Tata. 1954. In vitro conversion of thyroxine to triiodothyronine by kidney slices. Proc. Soc. Exp. Biol. Med. 86: 137-140.

2. Maclagan, N. F., and W. E. Sprott. 1954. The in vitro deiodination of thyroxine and triiodothyronine. Lancet. II: $368-369$.

3. Flock, E. V., and J. L. Bollman. 1955. The metabolism of thyroxine and triiodothyronine in the eviscerated rat. J. Biol. Chem. 214: 709-721.

4. Pitt-Rivers, R., J. B. Stanbury, B. Rapp. 1955. Conversion of thyroxine to $3,5,3$ '-triiodothyronine in vivo. J. Clin. Endocrinol. Metab. 15: 616-620.

5. Hagness, J. R., M. Berg, P. P. Van Arsdel, and R. H. Williams. 1955. Tissue conversion of thyroxine to triiodothyronine. Proc. Soc. Exp. Biol. Med. 90: 93-97.

6. Tata, J. R., J. E. Rall, and R. W. Rawson. 1957. Metabolism of L-thyroxine and L-3,5,3'-triiodothyronine by brain tissue preparations. Endocrinology. 60: 83-98.

7. Becker, D. V., and J. F. Prudden. 1959. The metabolism of $\mathrm{I}^{131}$-labeled thyroxine, triiodothyronine, and diiodotyrosine by an isolated perfused rabbit liver. Endocrinology. 64: 136-148.

8. Grinberg, R., E. M. Volpert, and S. C. Werner. 1963. In vitro deiodination of labelled L-thyroxine to L-3,5,3'triiodothyronine in mouse and human pituitaries. $J$. Clin. Endocrinol. Metab. 23: 140-142.

9. Green, W. L. 1978. Metabolism of thyroid hormones by rat thyroid tissue in vitro. Endocrinology. 103: 826-837.

10. Braverman, L. E., S. H. Ingbar, and K. Sterling. 1970. Conversion of thyroxine to triiodothyronine in athyreotic human subjects. J. Clin. Invest. 49: 855-864.

11. Pittman, C. S., J. B. Chambers, and V. H. Read. 1971. The extrathyroidal conversion rate of thyroxine to triiodothyronine in normal man. J. Clin. Invest. 50; $1187-$ 1196.

12. Surks, M. I., A. R. Schadlow, J. M. Stock, and J. H. Oppenheimer. 1973. Determination of iodothyronine absorption and conversion of L-thyroxine $\left(\mathrm{T}_{4}\right)$ to $\mathrm{L}$ triiodothyronine $\left(\mathrm{T}_{3}\right)$ using turnover techniques. J. Clin. Invest. 52: 805-811.

13. Braverman, L. E., A. Vagenakis, P. Downs, A. E. Foster, K. Sterling, and S. H. Ingbar. 1973. Effects of replacement doses of sodium-L-thyroxine on the peripheral metabolism of thyroxine and triiodothyronine in man. J. Clin. Invest. 52: 1010-1017.

14. Chopra, I. J. 1974. A radioimmunoassay for measure- ment of $3,3^{\prime}, 5^{\prime}$-triiodothyronine (reverse $\mathrm{T}_{3}$ ). J. Clin. Invest. 54: 583-592.

15. Chopra, I. J. 1976. An assessment of daily production and significance of thyroidal secretion of 3,3',5-triiodothyronine (reverse $\mathrm{T}_{3}$ ) in man. J. Clin. Invest. 58: 32-40.

16. Chopra, I. J. 1977. Study of extrathyroidal conversion of thyroxine $\left(T_{4}\right)$ to $3,5,3^{\prime}$-triiodothyronine $\left(T_{3}\right)$ in vitro. Endocrinology. 101: 453-463.

17. Kaplan, M. M., and R. D. Utiger. 1978. Iodothyronine metabolism in rat liver homogenates. J. Clin. Invest. 61: 459-471.

18. Cavalieri, R. R., and B. Rapoport. 1977. Impaired peripheral conversion of thyroxine to triiodothyronine. Annu. Rev. Med. 28: 57-65.

19. Schimmel, M., and R. D. Utiger. 1977. Thyroidal and peripheral production of thyroid hormones. Ann. Intern. Med. 87: 760-768.

20. Eisenstein, A., S. Hagg, A. G. Vagenakis, S. L. Fang, B. Ransil, A. Burger, A. Balsam, L. E. Braverman, and S. H. Ingbar. 1978. Effect of starvation on the production and peripheral metabolism of $3,3^{\prime}, 5^{\prime}$-triiodothyronine in euthyroid obese subjects. J. Clin. Endocrinol. Metab. 47: 889-893.

21. Balsam, A., and S. H. Ingbar. 1978. The influence of fasting, diabetes, and several pharmacological agents on the pathways of thyroxine metabolism in rat liver. J. Clin. Invest. 62: 415-424.

22. Harris, A. R. C., S. Fang, A. G. Vagenakis, and L. E. Braverman. 1978. Effect of starvation, nutriment replacement, and hypothyroidism on in vitro hepatic $\mathrm{T}_{4}$ to $\mathrm{T}_{3}$ conversion in the rat. Metab. Clin. Exp. 27: 1680-1690.

23. Kochupillai, N., and R. S. Yalow. 1978. Preparation, purification and stability of high specific activity ${ }^{125}$ Ilabeled thyronines. Endocrinology. 102: 128-135.

24. Exton, J. E., and C. R. Park. 1967. Control of gluconeogenesis in liver. J. Biol. Chem. 242: 2622-2636.

25. Exton, J. E. 1975. The perfused rat liver. Methods Enzymol. 39: 3-36.

26. Soupart, P. 1962. Free amino acids of blood and urine in the human. In Amino acid pools. J. T. Holton, editor. Elsevier North-Holland, Inc., New York. pp. 220-262.

27. Woeber, K. A. 1978. L-Triiodothyronine and L-reversetriiodothyronine generation in the human polymorphonuclear leukocyte. J. Clin. Invest. 62: 577-584.

28. Lieblich, J., and R. D. Utiger. 1972. Triodothyronine radioimmunoassay. J. Clin. Invest. 51: 157-166.

29. Chopra, I. J. 1972. A radioimmunoassay for measurement of thyroxine in unextracted serum. J. Clin. Endocrinol. Metab. 34: 938-947.

30. Dunnett, C. W. 1970. Multiple comparisons. In Statistics in Endocrinology. J. W. McArthur and T. Colton, editors. The M.I.T. Press, Cambridge, Mass., pp. 86-87.

31. Kaplan, M. M., and R. D. Utiger. 1978. Iodothyronine metabolism in liver and kidney homogenates from hyperthyroid and hypothyroid rats. Endocrinology. 103: 156-161.

32. Balsam, A., F. Sexton, and S. H. Ingbar. 1978. The effect of thyroidectomy, hypophysectomy and hormone replacement on the formation of triiodothyronine from thyroxine in rat liver and kidney. Endocrinology. 103: 1759-1767.

33. Burman, K. D., Y-Y. Djuk, P. Kesler, and L. Wartofsky. 1978. The effect of $T_{4}$ administration of hepatic conversion of $T_{4}$ to $T_{3}$ in states of altered carbohydrate economy. 60th Annual meeting of the Endocrine Society. Abstr. 32.

34. Chopra, I. J. 1978. Sulfhydryl groups and the monodeiodination of thyroxine to triiodothyronine. Science (Wash. D. C.). 199: 904-905. 
35. Harris, A. R. C., S-L. Fang, J. Prosky, L. E. Braverman, and A. G. Vagenakis. 1978. Decreased outer ring monodeiodination of thyroxine and reverse triiodothyronine in the fetal and neonatal rat. Endocrinology. 103: 2216-2222.

36. Kaplan, M. M. 1979. Subcellular alterations causing reduced hepatic thyroxine-5'-monodeiodinase activity in fasted rats. Endocrinology. 104: 58-64.

37. Harris, A. R. C., S. Fang, K. Kinerfeld, L. E. Braverman, and A. G. Vagenakis. 1979. The role of sulfhydryl groups on the impaired hepatic 3',3,5-triiodothyronine generation from thyroxine in the hypothyroid, starved, fetal, and neonatal rodent. J. Clin. Invest. 63: 516-524.

38. Balsam, A., and S. H. Ingbar. 1979. Observations on the factors that control the generation of triiodothyronine from thyroxine in rat liver and the nature of the defect induced by fasting. J. Clin. Invest. 63: 1145-1156.

39. Yamada, T., N. Kaplowitz, and I: J. Chopra. 1978. Mechanism of propylthiouracil (PTU) inhibition of hepatic thyroxine $\left(\mathrm{T}_{4}\right) 5^{\prime}$-monodeiodination. Clin. Res. 26: 660A. (Abstr.)

40. Flock, E. V., and C. A. Owen, Jr. 1965. Metabolism of thyroid hormones and some derivatives in isolated perfused rat liver. Am. J. Physiol. 209: 1039-1045.

41. Freinkel, N., S. H. Ingbar, and J. T. Dowling. 1957. The influence of extracellular thyroxine-binding protein upon the accumulation of thyroxine by tissue slices. J. Clin. Invest. 36: 25-37.

42. Gorman, C. A., E. V. Flock, C. A. Owen, Jr., and J. Paris. 1966. Factors affecting exchange of thyroid hormone between liver and blood. Endocrinology. 179: 391-405.

43. Cavalieri, R. R., and G. L. Searle. 1966. The kinetics of the distribution between plasma and liver of ${ }^{131}$ I-labeled L-thyroxine in man: observations of subjects with normal and decreased serum thyroxine-binding globulin. J. Clin. Invest. 45: 939-949.

44. Oppenheimer, J. H., G. Bernstein, and M. I. Surks. 1968. Increased thyroxine turnover and thyroidal function after stimulation of hepatocellular binding of thyroxine by phenobarbital. J. Clin. Invest. 47: 1399-1406.

45. Hillier, A. P. 1971. The mechanism of thyroxine transfer from plasma to tissue binding sites. J. Physiol. (Lond.). 217: 635-639.

46. Samuels, H. H., and T. S. Tsai. 1974. Thyroid hormone action: demonstration of similar receptors in isolated nuclei of rat liver and cultured GH cells. J. Clin. Invest. 53: 656-659.
47. Oppenheimer, J. H., H. L. Schwartz, D. Koerner, and M. I. Surks. 1974. Limited binding capacity sites for Ltriiodothyronine in rat liver nuclei: nuclear-cytoplasmic interrelation, binding constants and cross-reactivity with L-thyroxine. J. Clin. Invest. 53: 768-777.

48. Sterling, K., and P. O. Milch. 1975. Thyroid hormone binding by a component of mitochondrial membrane. Proc. Natl. Acad. Sci. U. S. A. 72: 3225-3229.

49. Sterling, K., P. O. Milch, M. A. Brenner, and J. H. Lazarus. 1977. Thyroid hormone action: the mitochondrial pathway. Science (Wash. D. C.). 197: 996-999.

50. Schwartz, H. L., G. Bernstein, and J. H. Oppenheimer. 1969. Effect of phenobarbital administration on the subcellular distribution of ${ }^{125} \mathrm{I}$-thyroxine in rat liver: importance of microsomal binding. Endocrinology. 84: 270276.

51. Davis, P. J., B. S. Handwerger, and F. Glaser. 1974. Physical properties of a dog liver and kidney cytosol protein that binds thyroid hormone. J. Biol. Chem. 249: 6208-6217.

52. Lichter, M., G. Fleischner, R. Kirsch, A. J. Levi, K. Kamisaka, and I. M. Arias. 1976. Ligandin and $\mathrm{Z}$ protein in binding of thyroid hormones by the liver. Am. J. Physiol. 230: 1113-1120.

53. Tata, J. R. 1964. Distribution and metabolism of thyroid hormones. In The Thyroid Gland. R. Pitt-Rivers and W. B. Trotter, editors. Butterworth \& Co., Kent, England. pp. 163-186.

54. Pliam, N. B., and I. D. Goldfine. 1977. High affinity thyroid hormone binding sites on purified rat liver plasma membranes. Biochem. Biophys. Res. Commun. 79: 166172.

55. DeGroot, L. J., A. H. Coleoni, P. A. Rue, H. Seo, E. Martino, and S. Refetoff. 1977. Reduced nuclear triiodothyronine receptors in starvation-induced hypothyroidism. Biochem. Biophys. Res. Commun. 79: 172-179.

56. Burman, K. D., Y. Lukes, F. D. Wright, and L. Wartofsky. 1977. Reduction in hepatic triiodothyronine binding capacity induced by fasting. Endocrinology. 101: 13311334.

57. Schussler, G. C., and J. Orlando. 1978. Fasting decreases triiodothyronine receptor capacity. Science (Wash. D. C.). 199: 686-688.

58. Stein, L. B., S. Mishkin, G. Fleischner, Z. Gatmaitan, and I. M. Arias. 1976. Effect of fasting on hepatic ligandin, Z. protein, and organic anion transfer from plasma in rats. Am. J. Physiol. 231: 1371-1376. 